\section{Nyttig om produksjonen av medisinske sanningar}

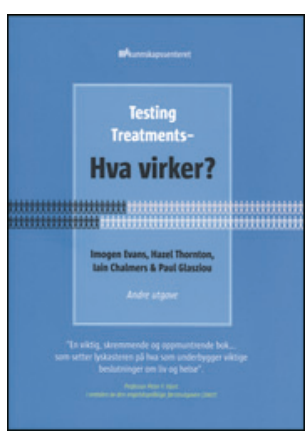

\author{
Imogen Evans, Hanzel Thornton, \\ lain Chalmers et al. \\ Testing Treatments - Hva virker? \\ 2. utg. 197 s, tab, ill. Oslo: Kunnskapssenteret, \\ 2013. Pris Gratis nedlastbar \\ ISBN 978-82-8121-541-2
}

For sju år sidan skreiv Peter F Hjort ei omtale av den engelske førsteutgåva og kalla den «viktig, skremmende og oppmuntrende». Denne karakteristikken er det rimeleg lett å slutte seg til, sjølv om den gode Peter Hjort nok ville ha leitt etter oppmuntrande teikn på at dei problemstillingane forfattarane tek opp, får tilfredsstillande merksemd mellom beslutningstakarar og utøvarar og i allmenta.

Første utgåva fekk stor merksemd, og den engelske versjonen av andre utgåve kom i 2011. I tillegg til ein revidert tekst har det i denne utgåva mellom anna kome til eit kapittel om screening og eit kapittel om forskingsetikk. Det er andre utgåve Kunnskapssenteret no prisverdig nok har fått omsett, og som er lagt ut på nettet til fri nedlasting.

Kort fortalt er boka ei kritisk, men etter mi meining balansert, framstilling av prosessane, drivarar og fallgruver knytt til produksjonen av medisinske sanningar. Den er halden i eit enkelt språk, og layouten er spartansk. Målgruppa er svært brei, frå pårørande og pasientar til helsearbeidarar og kliniske forskarar. Det kan synast halselaust å ha ambisjonar om å nå fram så breitt, og sjølv om framstillinga støttar desse ambisjonane, vil det nok vere mellom helsestudentar og helsearbeidarar at boka vil bli høgast verdsett.

Boka er svært lettlest, den har om lag 155 sider tekst, og denne er delt inn i 13 korte kapittel med oppsummerande hovudpunkt. Kapitteloverskriftene inneheld titlar som $N y$ - men er den bedre?, Mer er ikke nødvendigvis bedre, Hvordan håndtere usikkerhet i forbindelse med medisinsk behandling? og Ta hensyn til tilfeldighetenes spill.

Dette er ikkje ei lærebok i forskingsmetode, snarare gjev den nyttige og spennande vinklingar og perspektiv på det ein får presentert som dokumentasjon, og som ein sjeldan eller aldri finn i lærebøker. Nærast til ei lærebok vil den vere innanfor feltet kunnskapshandtering, som etter kvart er vorte pensum ved dei fleste helseutdanningane.

Men vi kan ikkje vente til den neste generasjonen helsearbeidarar får augo opp og is i magen. Alle som tek avgjerder i helsetenesta, treng denne boka no, frå dei som sit pasientane nærast, til dei som tek dei store overordna beslutningane på helsepolitisk nivå. Dei vil alle ha stor nytte av å lese denne vesle boka. Nokre få vil vere kritiske og skuffa over å miste sin over-entusiasme, sin over-optimisme og skråsikkerheit, men dei fleste vil nikke attkjennande til dei mange kritiske perspektiva.

Til både den engelske og den norske utgåva er det utvikla nettsider som inneheld lenker til ekstra ressursar, som hjelp, forklaring og illustrasjon av prinsippa og bodskapane.

\section{Omfattende, men uoversiktlig om immunsvikt}

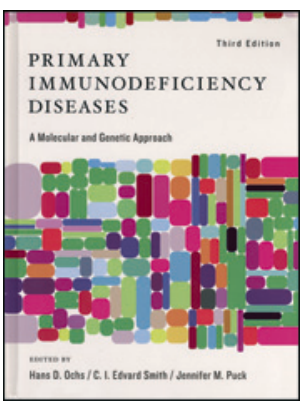

Hans D. Ochs, C. I. Edvard Smith,

Jennifer M. Puck, red.

Primary immunodeficiency diseases

A molecular and genetic approach. 3. utg.

911 s, tab, ill. Oxford: Oxford University Press, 2013. Pris GBP 163

ISBN 978-0-19-538983-8

Primær immunsvikt omfatter tilstander der medfødte svakheter i immunsystemet fører til økt infeksjonstendens, kreftsykdom og/eller autoimmunitet med debut fra spedbarnsalder til godt opp i voksen alder.

Den rivende utviklingen innenfor molekylærbiologi og genetikk har ført til stor endring både i forståelse og diagnostikk av disse tilstandene. Behovet for å systematisere og samle denne kunnskapen er åpenbar. Det er derfor et prisverdig mål de tre redaktørene og mer enn 100 forfattere av denne tredje utgaven har satt seg. Dessverre er det synd å si at de bare delvis har lyktes.

Boken er angitt å appellere til både studenter, primærleger og sykehusspesialister, men fremstår først og fremst som en bok for spesialister med ansvar for oppfølging av denne typen pasienter, dvs. barneleger og infeksjonsmedisinere.

De fleste av de 61 kapitlene omhandler en eller få nært beslektede immunsvikttilstander, og det er slik sett lett å slå opp en enkelt tilstand. Forfatterlisten inkluderer velrennomerte klinikere og forskere som generelt skriver godt og oppdatert i sine respektive kapitler. De enkelte kapitlene varierer imidlertid både i struktur, tematikk og bruk av figurer og tabeller. Noen legger vekt på genetikk, andre på molekylære funn eller klinisk arbeid. Det er dermed vanskelig å sammenlikne forskjellige tilstander og forstå hvilke kriterier som har ligget til grunn for prioritering av temaene.

I enkelte kapitler gir man en generell introduksjon til en større gruppe immunsvikttilstander, bl.a. alvorlig kombinert immundefekt (severe combined immunodeficiency, SCID) og B-celle-defekter, men også disse kapitlene varierer svært i omfang og oppbygning. Boken fremstår derfor som en samling av i og for seg gode oversiktsartikler om de enkelte sykdommene. Tilsvarende artikler med mange av de samme forfatterne - kan man like gjerne laste ned fra PubMed, og da kan man spørre seg hvorfor man skal kjøpe disse i bokform til en relativt stiv pris.

Immunologi og genetikk er kompliserte temaer som krever stram regi og systematikk for å formidles på en forståelig måte. Redaktørene angir i undertittelen at boken er «a molecular and genetic approach», men de kan med fordel også forsøke «a pedagogic approach» ved neste utgivelse.

\section{Børre Fevang}

Lege i spesialisering, Seksjon for klinisk immunologi

og infeksjonssykdommer

Oslo universitetssykehus, Rikshospitalet 